\title{
Study on Factors that Contribute towards Open Distance Learning Contentment in Mathematics among UiTM Tapah Students: Exploratory Factor Analysis
}

Farah Waheeda Azhar, Nurul Husna Jamian, Mohd Hafiz Mohammad Hamzah and Wan Noor Hayatie Wan Abdul Aziz

To Link this Article: http://dx.doi.org/10.6007/IJARBSS/v11-i9/11060 DOI:10.6007/IJARBSS/v11-i9/11060

Received: 07 July 2021, Revised: 01 August 2021, Accepted: 29 August 2021

Published Online: 17 September 2021

In-Text Citation: (Azhar et al., 2021)

To Cite this Article: Azhar, F. W., Jamian, N. H., Hamzah, M. H. M., \& Aziz, W. N. H. W. A. (2021). Study on Factors that Contribute towards Open Distance Learning Contentment in Mathematics among UiTM Tapah Students: Exploratory Factor Analysis. International Journal of Academic Research in Business and Social Sciences, 11(9), 705-716.

\section{Copyright: (c) 2021 The Author(s)}

Published by Human Resource Management Academic Research Society (www.hrmars.com) This article is published under the Creative Commons Attribution (CC BY 4.0) license. Anyone may reproduce, distribute, translate and create derivative works of this article (for both commercial and non-commercial purposes), subject to full attribution to the original publication and authors. The full terms of this license may be seen at: http://creativecommons.org/licences/by/4.0/legalcode

Vol. 11, No. 9, 2021, Pg. 705 - 716 


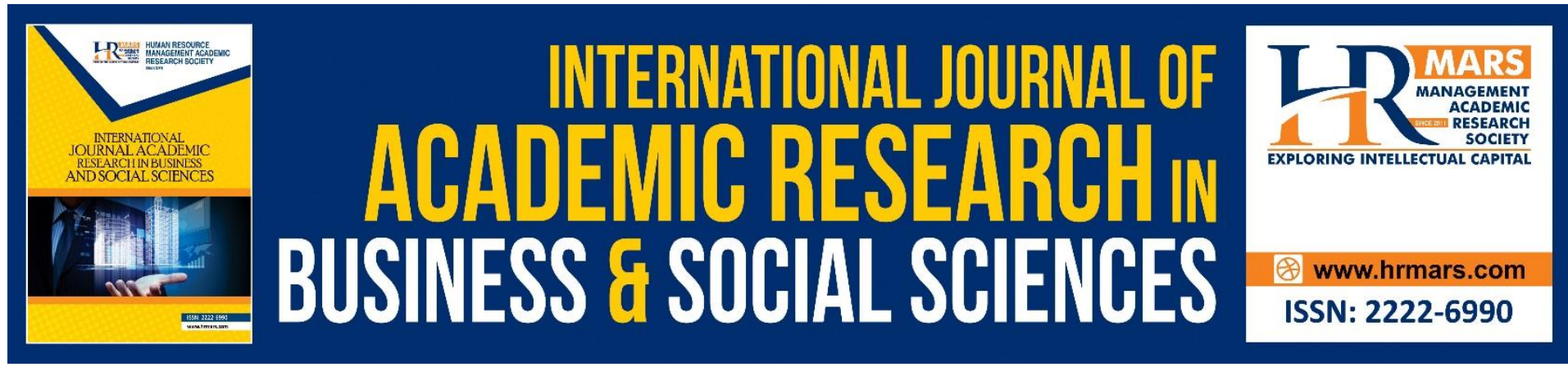

\title{
Study on Factors that Contribute towards Open Distance Learning Contentment in Mathematics among UiTM Tapah Students: Exploratory Factor Analysis
}

\author{
Farah Waheeda Azhar, Nurul Husna Jamian, Mohd Hafiz \\ Mohammad Hamzah and Wan Noor Hayatie Wan Abdul Aziz \\ Faculty of Computer and Mathematical Sciences, Universiti Teknologi MARA, Perak Tapah \\ Campus, Tapah Road, 35400 Perak, MALAYSIA
}

\begin{abstract}
The number of positive cases raised over 553 cases on the 16th March 2020. Thus, the Prime Minister of Malaysia announced a Movement Control Order (MCO) starting from 18th March to 31st March 2020. After two weeks, the teaching and learning ( $T n L)$ process implemented with a new learning policy at home through online learning and UiTM started Open Distance Learning (ODL) on 12th April 2020 in order to complete the courses in the given period. There are lack of universities practicing with ODL before including UiTM Tapah. Teaching Mathematics via online was very challenging as students are accustomed to the method of Face to Face (F2F) learning since early education. In addition, students were commonly less proficient in spelling and mathematical calculations compared to reading skills. The educators must understand students' background and identify the factors which may affect the learning process. Therefore, this study intends to identify the factors that contribute on students' contentment towards ODL during COVID-19 pandemic. A set of questionnaire constructed using Google form consists of Personal Information ( 5 items) and ODL information (32 items) sections. Then, the Google form link is shared via Whatsapp and Telegram application. A sample of 336 students who experienced learning Mathematics course through ODL from various faculties in UiTM Tapah were responded to the questionnaire. This study applied convenience sampling method. This study executed Descriptive Analysis and Exploratory Factor Analysis (EFA). It found that there are five factors that contribute towards ODL Contentment in Mathematics among UiTM Tapah students which were Online Learning Readiness, Self-Directed Learning, Technologies, Internet, and Tools, Skills and Acceptance and Motivation for Learning.
\end{abstract}

Keywords: COVID-19, Open Distance Learning, Mathematics, Exploratory Factor Analysis

\section{Introduction}

The World Health Organization (WHO) announced a new epidemic outbreak recognized as SARS-CoV-2 then it officially named as coronavirus disease 2019 (COVID-19) on the 12th 
January 2020 (Allam et al., 2020). The first case of COVID-19 was found in Malaysia and traced back to three Chinese nationals who previously had close contact with an infected person in Singapore (Clark et al., 2021; Hoofman \& Secord, 2021). Meanwhile the first Malaysian was confirmed with COVID-19 on the 4th February 2020. The 41-year old man had recently returned from Singapore when he started to develop a fever and a cough. He was quarantined at Sungai Buloh Hospital, Selangor (Yahya et al., 2021). As the number of positive cases raised over 553 cases on the 16th March 2020. Thus, the Prime Minister of Malaysia announced a Movement Control Order (MCO) starting from 18th March to 31st March 2020 (Ministry of Health Malaysia, 2020). Hence, the top management of every sector made quick and relevant decisions about their operations.

The higher education institutions and universities' management very concerned on this urgency of MCO and directed all universities' students return to their home. After two weeks, the teaching and learning ( $T n L)$ process among many universities just started to be implemented with a new learning policy at home through online learning where majority of higher education institutions dealing with Open Distance Learning (ODL) during this pandemic (Noor et al., 2020). Distance learning refers to a method of delivering contents and interaction between educators and learners through online communication technologies and tools (Stauffer, 2020).

The transformation of learning style form face to face (F2F) to ODL changed the education process among the academicians and students. This dramatic change is an effort from government to protect communities from being a victim of this pandemic while education learning needs to be continued (Shah et al., 2021). There are lack of universities practicing or experiencing with ODL before including UiTM Tapah. However, educators and learners are responsible to complete the courses in the given period through ODL (Aziz et al., 2021). Regardless they had no alternative to engage with learning activities except the ODL to complete their courses. UiTM started ODL on 12th April 2020. Prior to fully adopted ODL, blended learning (BL) was used to particular courses by integrating $\mathrm{F} 2 \mathrm{~F}$ and online TnL. However, the overall contentment towards the BL practices are still low (Abu Seman et al., 2019).

Mathematics is a core subject that has come to people apprehension. In Mathematics, educators previously teaching in F2F way using many symbols and formulas that they are used to writing on whiteboard for their students to see and understand (Okoye et al., 2021). In contrast to ODL, it is recognized that students who do not self-regulated in learning will face difficulties in engaging online learning, comprehension problems in Mathematics and tend to receive incorrect instructions from the educators. That is the reason why Mathematics achievement has often been focused because it considered as a tough subject. The shift to online learning during the COVID-19 pandemic was a big challenge among academicians (Kuhfeld et al., 2020). Educators must address students' challenges and obstacles during online learning activities by understanding students' backgrounds and identifying factors that can influence the learning process. Therefore, this study aimed to identify the factors that contribute to students' contentment towards ODL in learning Mathematics during the COVID19 pandemic.

\section{Literature Review}

Since COVID-19 outbreak has hit in 2019, the education division has almost completely changed the way of TnL from all levels. Due to this situation, most of the education division practiced an online TnL process instead of physical meeting before (Clark et al., 2021; 
Hoofman \& Secord, 2021). Generally, the main purpose of education is to convey knowledge and information. The transition of $\mathrm{TnL}$ requires educators to communicate actively with their students, encourage them to participate and enjoy the $\mathrm{TnL}$ process even they came from various areas and conditions (Rafique et al., 2021; Yahya et al., 2021; YM et al., 2021). Distance learning may facilitate a pedagogical transition from an educator centered approach to a learner centered approaches where the students closely interact with their educators and other students (Shah et al., 2021; Veronika et al., 2021).

Teaching Mathematics via online was very challenging as students are accustomed to the method of F2F learning since early education (El Refae et al., 2021; Nugroho et al., 2021). It found that students were commonly less proficient in spelling and mathematical calculations skills compared to reading skills (Kuhfeld et al., 2020; Pavlovic et al., 2021). Thus, educator plays an important role to diversifying teaching methods creatively in order to attract student's attention and participation during online class session. (Chukwuemeka et al., 2021; Okoye et al., 2021). Besides, students must had additional efforts such as watching online lectures on YouTube or purchase optional remote learning sources such as question banks (El Refae et al., 2021).

Contentment refers to a pleasant feeling when people received something they wanted or when people have done something they wanted to do (Cambridge Advanced Learner's Dictionary, 2008). The ODL contentment refers to student's perceived value of their educational experiences (Astin, 1993). It depends on the attitudes and perceptions that could be influenced by other factors. There are several factors leading to the level of contentment among students in ODL. Some studies have reported the quality of distance learning technologies and tools (Haddad et al., 2014), the method and approach of teaching styles (Cheng et al., 2017), and skills and acceptance (Kamalluarifin et al., 2018) can affect the ODL contentment among students.

A study by El Refae et al. (2021) and Okoye et al. (2021), it found that technology readiness, self-directed learning, learner control and online communications contributed to the ODL contentment in Mathematics. Another study by Chukwuemeka et al. (2021) revealed that students in Pakistan were motivated to learn online, more receptive to new ideas and willing to interact among their classmates throughout online learning since the first lockdown announced by their government. For first year students, a "Campus Free" approach was introduced to ensure students are mentally, emotionally and physically prepared to online learning so that they keep happy and motivated with ODL learning style (Zafar \& Dayat, 2000).

Besides, it is undeniable the important of a good online devices and internet connection to the contentment of ODL among students (Yusof \& Ahmad, 2012; Haddad et al., 2014). Furthermore, it is important to make students more comfortable in online learning at a minimum usage of internet data and device specification (Chukwuemeka et al., 2021; Nugroho et al., 2021; Saidi et al., 2021) . Thus, the role of parents to provide advice and assistant, educators to motivate and to innovate the learning process and classmates able to communicate and discuss the learning topics or assignment in order to maintain the stability of student's learning motivation (Luca et al., 2021; Maboe, 2017; Shahrvini et al., 2021).

\section{Methodology}

This study performed primary data collection by initially constructing a set of questionnaires using Google form consists of two sections which are Personal Information and ODL information. Overall, there are five questions in the first section and 32 questions in the second section. In order to validate the statements of questionnaire, the research members 
have shared the Google form link via Whatsapp application together with the feedback form to some experts such as educators and students, then they reviewed that questionnaire. The questionnaire was amended based on the experts' comments and suggestions. The questionnaire designed using 5-point Likert scale representing a level such 1 is strongly disagree, 2 is disagree, 3 is neutral, 4 is agree and 5 is strongly agree.

The population in this study is the entire diploma students who enrolled in UiTM Tapah who experienced learning Mathematics course through ODL. A sample of 336 students who experienced learning Mathematics course through ODL from various faculties in UiTM Tapah were responded to the questionnaire. This study applied convenience sampling method because it is incredibly prompt, uncomplicated, and economical. The factors involved is displayed on Figure 2.

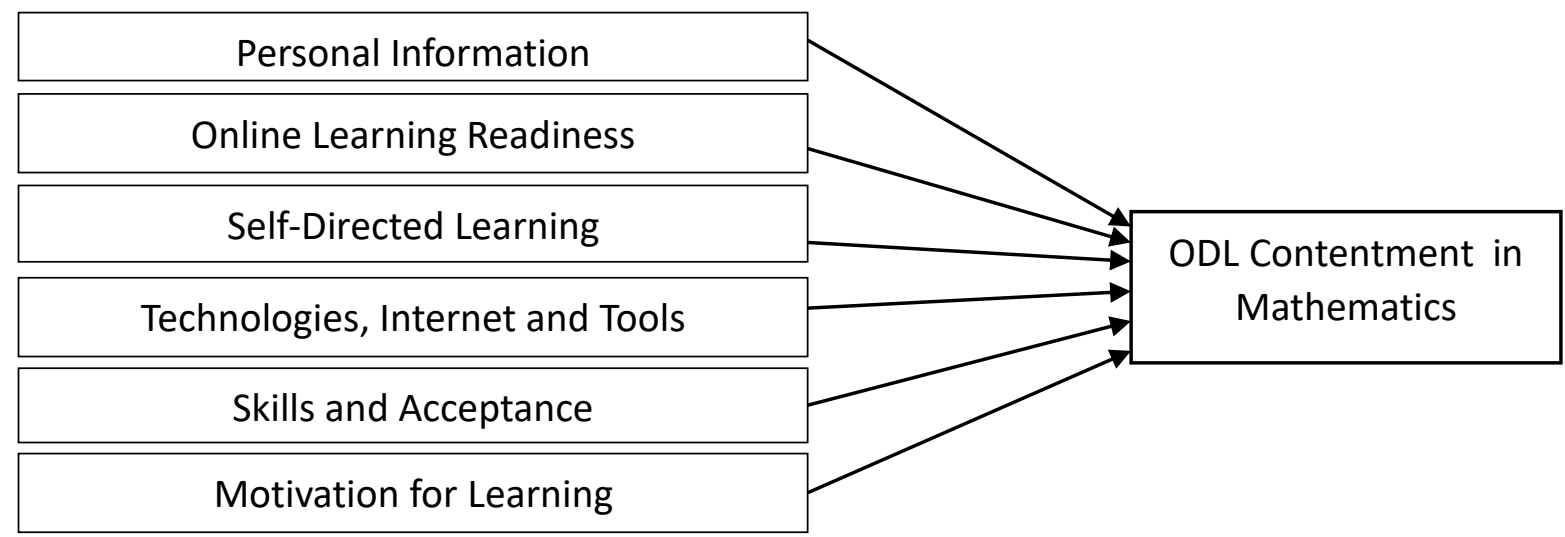

Figure 1. Conceptual Framework on ODL Contentment

This study executed two analyses which are Descriptive Analysis and Exploratory Factor Analysis (EFA) using IBM SPSS Statistics software. Descriptive Analysis is presented the Personal Information in term of frequency and percentage. The EFA begin by testing for normality using skewness statistic for each item followed by component extraction and testing for reliability. Normality test is performed to determine whether a dataset is modeled for normal distribution. This study considered skewness statistic to measure the asymmetry of each item. The normality assumption is fulfilled when skewness statistic lies between range -1 and 1 (Aziz et al., 2018; Zulkipli et al., 2018).

To ensure the data is relevant for EFA this study take into account Kaiser-Meyer-Olkin (KMO) Measure of Sampling Adequacy. KMO statistic varies between 0 and 1. According to (Kaiser, 1974), it recommended accepting KMO statistic greater than 0.5 as barely acceptable. $\mathrm{KMO}$ values less than 0.5 should lead to more data collection or choosing variables to include. It described KMO statistic between 0.5 and 0.7 is mediocre, between 0.7 and 0.8 is good, between 0.8 and 0.9 is great, and more than 0.9 is superb. Then, Bartlett's Test of Sphericity is considered and it significant at $p$-value less than 0.001 . It means that adequate correlation among items to proceed with factor analysis (Field, 2000).

The reliability of the questionnaire is then assessed using the Cronbach's Alpha statistic. If the statistic is greater than 0.7 , it explained that all items enter in each factor are reliable for further analysis and it pointed out that all factors extracted also reliable measuring the consistency of respondents responses (Chinna, 2009; Nunally 1978). For Component extraction procedure, it assumed adequate for further analysis when the total variance obtained is at least 50\% (Habidin et al., 2015; Zakuan, 2009; Streiner, 1994). This study also 
considers at least 0.4 loads for every item to be included in an underlying factor (Aziz et al., 2018; Zulkipli et al., 2018).

\section{Statistical Analysis \\ Descriptive Analysis}

Table 1 showed the frequency and percentage of each attribute that represents the respondents' background in this study. Majority of respondents were female by $74.4 \%$ ( 250 respondents) and the remaining $25.6 \%$ (86 respondents) were male. According to age group, majority of the respondents aged between 18 and 20 years old by $81.5 \%$ ( 274 respondents) meanwhile the rest was aged between 21 and 23 years old by $18.5 \%$ ( 62 respondents). Referring to faculty, most of the respondents were from Faculty of Computer and Mathematical Sciences (FSKM) by 60.1\% (202 respondents) followed by Faculty of Applied Sciences (FSG) by $28.9 \%$ (97 respondents) and another $11 \%$ (37 respondents) from Faculty of Accountancy (AC). It found that almost half of total respondents were from part 3 by $49.4 \%$ (166 respondents) followed by part 1 by $25 \%$ ( 84 respondents), part 5 by $12.5 \%$ (42 respondents), part 2 by $6.8 \%$ ( 23 respondents) and part 4 by $6.3 \%$ ( 21 respondents). For location of ODL, more than half of students performed their ODL at home where located in urban area by $51.8 \%$ (174 respondents) meanwhile respondents who their home located at rural area by $46.7 \%$ ( 157 respondents) and only 1.5\% (5 respondents) performed their ODL in campus college. For internet access performance, half of respondents which was $51.8 \%$ (174 respondents) rated good followed by $28.9 \%$ (97 respondents) rated very good, $9.2 \%$ (31 respondents) rated poor, $8.6 \%$ (29 respondents) rated excellent and only $1.5 \%$ (5 respondents) rated very poor connection. By describing the most preferred online teaching method in learning Mathematics, it found that majority of the respondents which was $74.4 \%$ (250 respondents) preferred Pre-recorded (video) lecture uploaded to any online platform followed by $19.6 \%$ (66 respondents) preferred Zoom/Google meet/Webex, $5.4 \%$ (18 respondents) preferred Whatsapp/Telegram and another $0.6 \%$ (2 respondents) preferred Microsoft team. 
Table 1. Descriptive analysis of Personal Information

\begin{tabular}{|c|c|c|c|}
\hline Factors & Attribute & Frequency & Percentage (\%) \\
\hline \multirow[t]{2}{*}{ Gender } & Male & 86 & 25.6 \\
\hline & Female & 250 & 74.4 \\
\hline \multirow[t]{2}{*}{ Age group (years) } & $18-20$ & 274 & 81.5 \\
\hline & $21-23$ & 62 & 18.5 \\
\hline \multirow[t]{3}{*}{ Faculty } & $\mathrm{AC}$ & 37 & 11.0 \\
\hline & FSG & 97 & 28.9 \\
\hline & FSKM & 202 & 60.1 \\
\hline \multirow[t]{5}{*}{ Part } & 1 & 84 & 25.0 \\
\hline & 2 & 23 & 6.8 \\
\hline & 3 & 166 & 49.4 \\
\hline & 4 & 21 & 6.3 \\
\hline & 5 & 42 & 12.5 \\
\hline \multirow[t]{3}{*}{ Location of ODL } & College & 5 & 1.5 \\
\hline & Home (urban area) & 174 & 51.8 \\
\hline & Home (rural area) & 157 & 46.7 \\
\hline \multirow{5}{*}{$\begin{array}{l}\text { Internet access } \\
\text { performance }\end{array}$} & Excellent & 29 & 8.6 \\
\hline & Very good & 97 & 28.9 \\
\hline & Good & 174 & 51.8 \\
\hline & Poor & 31 & 9.2 \\
\hline & Very poor & 5 & 1.5 \\
\hline \multirow[t]{4}{*}{$\begin{array}{l}\text { Online teaching } \\
\text { method } \\
\text { preference }\end{array}$} & $\begin{array}{c}\text { Pre-recorded (video) lecture } \\
\text { uploaded to any online } \\
\text { platform }\end{array}$ & 250 & 74.4 \\
\hline & Zoom/Google meet / Webex & 66 & 19.6 \\
\hline & Microsoft team & 2 & 0.6 \\
\hline & Whatsapp/Telegram & 18 & 5.4 \\
\hline
\end{tabular}

\section{Testing for Normality}

Table 2 showed that all skewness statistics fall within the range -1 and 1 . It claimed that the data was normally distributed and qualified to continue with EFA. 
Table 2. Skewness statistic of each item

\begin{tabular}{|c|c|c|c|}
\hline Item & Skewness Statistics & Item & Skewness Statistic \\
\hline Q1 & -0.392 & Q17 & -0.280 \\
\hline Q2 & -0.230 & Q18 & -0.115 \\
\hline Q3 & -0.369 & Q19 & -0.087 \\
\hline Q4 & -0.754 & Q20 & -0.282 \\
\hline Q5 & -0.422 & Q21 & -0.016 \\
\hline Q6 & -0.170 & Q22 & -0.178 \\
\hline Q7 & 0.266 & Q23 & -0.175 \\
\hline Q8 & 0.049 & Q24 & -0.063 \\
\hline Q9 & -0.222 & Q25 & -0.861 \\
\hline Q10 & 0.102 & Q26 & 0.203 \\
\hline Q11 & 0.063 & Q27 & -0.782 \\
\hline Q12 & -0.033 & Q28 & -0.735 \\
\hline Q13 & -0.621 & Q29 & -0.186 \\
\hline Q14 & -0.062 & Q30 & -0.697 \\
\hline Q15 & -0.093 & Q31 & -0.618 \\
\hline Q16 & -0.076 & Q32 & -0.031 \\
\hline
\end{tabular}

\section{Exploratory Factor Analysis}

Exploratory factor analysis (EFA) is a part of multivariate statistical methods purposely to identify the smallest number of factors or known as latent variables. In addition, it used to identify the common factors that explain the order and structure among measured variable. Based on Table 3, Kaiser-Meyer-Olkin (KMO) showed the sampling adequacy as 0.913 greater than 0.5. It determined the sampling adequacy of data that are to be used for factor analysis. Then, Bartlett's Test of Sphericity, was significant at $p$-value lower than 0.001 , indicating sufficient correlation among items to proceed with the factor analysis as well.

Table 3. Result of KMO and Barlett's Test

\begin{tabular}{|l|c|}
\hline \multicolumn{1}{|c|}{ Test } & Statistic \\
\hline Kaiser-Meyer-Olkin (KMO) & 0.913 \\
Measure of Sampling Adequacy & \\
\hline Bartlett's Test of Sphericity: & \\
Approximation Chi-Square & 5597.736 \\
Degree of freedom & 496 \\
p-value & 0.000 \\
\hline
\end{tabular}

Five factors in initial solution was generated as presented in Table 4 where the factors contributed $58.3 \%$ from the total variance which is adequate for further analysis since it greater than $50 \%$. It also stipulated that the variance explained by extraction solution was $58.3 \%$. Hence, no doubt that total of five factors were accepted. This study accepted items with a minimum 0.4 loading to be included in a particular factor. The first factor named as Readiness made up of the 7 items. For second factor named as Self-learning ability made up of 10 items. Meanwhile, factor three, four and five named as Computer and internet facilities, Challenges and Motivation were made up of five items respectively. 
Table 4. Component Extraction

\begin{tabular}{|c|c|c|c|c|c|c|c|}
\hline Factor & Factor's name & Item & $\begin{array}{l}\text { Factor } \\
\text { Loading }\end{array}$ & Factor & $\begin{array}{l}\text { Factor's } \\
\text { name }\end{array}$ & Item & $\begin{array}{l}\text { Factor } \\
\text { Loading }\end{array}$ \\
\hline \multirow[t]{7}{*}{1} & \multirow{7}{*}{$\begin{array}{c}\text { Online Learning } \\
\text { Readiness }\end{array}$} & 6 & 0.678 & \multirow[t]{5}{*}{3} & \multirow{5}{*}{$\begin{array}{c}\text { Technologies, } \\
\text { Internet and } \\
\text { Tools }\end{array}$} & 1 & 0.731 \\
\hline & & 7 & 0.797 & & & 2 & 0.662 \\
\hline & & 8 & 0.763 & & & 3 & 0.750 \\
\hline & & 15 & 0.571 & & & 4 & 0.774 \\
\hline & & 16 & 0.833 & & & 5 & 0.699 \\
\hline & & 17 & 0.580 & \multirow[t]{5}{*}{4} & \multirow{5}{*}{$\begin{array}{c}\text { Skills and } \\
\text { Acceptance }\end{array}$} & 9 & 0.824 \\
\hline & & 18 & 0.806 & & & 10 & 0.812 \\
\hline \multirow[t]{10}{*}{2} & \multirow{10}{*}{$\begin{array}{l}\text { Self-Directed } \\
\text { Learning }\end{array}$} & 19 & 0.545 & & & 11 & 0.727 \\
\hline & & 20 & 0.572 & & & 12 & 0.723 \\
\hline & & 21 & 0.507 & & & 14 & 0.456 \\
\hline & & 22 & 0.442 & \multirow[t]{7}{*}{5} & \multirow{7}{*}{$\begin{array}{l}\text { Motivation } \\
\text { for Learning }\end{array}$} & 13 & 0.400 \\
\hline & & 23 & 0.590 & & & 25 & 0.405 \\
\hline & & 24 & 0.625 & & & 27 & 0.795 \\
\hline & & 26 & 0.739 & & & 28 & 0.635 \\
\hline & & 29 & 0.401 & & & \multirow[t]{3}{*}{31} & \multirow[t]{3}{*}{0.604} \\
\hline & & 30 & 0.493 & & & & \\
\hline & & 32 & 0.667 & & & & \\
\hline
\end{tabular}

\section{Reliability}

Table 5 showed the Cronbach's Alpha statistic for each factor. The Cronbach's Alpha statistic for Factor 1 (Online Learning Readiness), 2 (Self-Directed Learning), 3 (Technologies, Internet and Tools), 4 (Skills and Acceptance), and 5 (Motivation for Learning) were 0.899, 0.867, $0.844,0.808,0.733$ respectively. These values were greater than 0.7 presented that the questionnaire constructed was reliable indirectly it pointed out that all factors extracted also reliable measuring the consistency of respondent's perceptions.

Table 5. Testing for Reliability

\begin{tabular}{|c|c|}
\hline Factor & Cronbach's Alpha statistic \\
\hline 1 & 0.899 \\
\hline 2 & 0.867 \\
\hline 3 & 0.844 \\
\hline 4 & 0.808 \\
\hline 5 & 0.733 \\
\hline
\end{tabular}

\section{Conclusion}

As a conclusion, this study found that there are five factors that contribute on Students' Contentment towards Open Distance Learning in Mathematics. The set of questionnaires is classified according to relevancy of items that represent those particular factors such as Factor 1 (Online Learning Readiness), 2 (Self-Directed Learning), 3 (Technologies, Internet and Tools), 4 (Skills and Acceptance), and 5 (Motivation for Learning). In addition these factors are reliable and consistent to be used for quantitative analysis such as Confirmatory Factor Analysis in the future. 
It is hoped both educators and students have better in understanding the concept of ODL and work towards empowering the teaching and learning process in Mathematics.

\section{Acknowledgement}

The authors would like to thank Universiti Teknologi MARA, Perak Branch, Tapah Campus for the facilities and motivation supports to complete this study. Thanks to all respondents who participated in this study.

\section{Corresponding Author}

Farah Waheeda Azhar

Faculty of Computer and Mathematical Sciences, Universiti Teknologi MARA, Perak Branch, Tapah Campus, 35400 Tapah Road, Perak, Malaysia.

Email: farah154@uitm.edu.my.

\section{References}

Abu Seman, S. A., Hashim, M. J., Roslin, M. R., Ishar, M. N. I. (2019). Millennial Learners' Acceptance and Satisfaction of Blended Learning Environment. Asian Journal of University Education 15(3), 129-141.

Allam, S. N. S., Hassan, M. S., Mohideen, R. S., Ramlan, A. F., \& Kamal, R. M. (2020). Online Distance Learning Readiness During COVID-19 Outbreak Among Undergraduate Students. International Journal of Academic Research in Business and Social Sciences, 10(5). https://doi.org/10.6007/IJARBSS/V10-15/7236

Astin, A. W. (1993). What matters in college? Four critical years revisited. San Francisco, CA: Jossey-Bass.

Aziz, W. N. H. W. A., Aziz, W. N. H. W. A., Zulkipli, F., Hamzah, M. H. M., Azhar, F. W., \& Rahim, S. K. N. A. (2018). Investigating Job Satisfaction Using Exploratory Factor Analysis at ABC Factory. International Journal of Engineering \& Technology, 7(4.33), 56-59. https://doi.org/10.14419/ijet.v7i4.33.23484

Cambridge University Press. (2008), Cambridge Advanced Learner's Dictionary, Cambridge University Press, Cambridge, UK.

Cheng, F. F., Chiu, C. C., Wu, C. S., \& Tsaih, D. C. (2017), "The Influence of Learning Style on Satisfaction and Learning Effectiveness in The Asynchronous Web-Based Learning System", Library Hi Tech, Vol. 35 No. 4, pp. 473-489.

Chinna, K. (2009). Structural Equation Modeling Using AMOS. Kuala Lumpur: Malaysia. Chukwuemeka, E. J., Dominic, S., Kareem, M. A., \& Mailafia, I. A. (2021). Redesigning Educational Delivery Systems: The Needs And Options For Continuous Learning During The Coronavirus (COVID-19) Pandemic in Nigeria. Contemporary Educational Technology, 13(1), ep292. https://doi.org/10.30935/CEDTECH/9363

Clark, A. E., Nong, H., Zhu, H., \& Zhu, R. (2021). Compensating for Academic Loss: Online Learning and Student Performance during the COVID-19 Pandemic. China Economic Review, 68. https://doi.org/10.1016/j.chieco.2021.101629

El Refae, G. A., Kaba, A., \& Eletter, S. (2021). Distance Learning during COVID-19 Pandemic: Satisfaction, Opportunities and Challenges as Perceived by Faculty Members and Students. Interactive Technology and Smart Education. https://doi.org/10.1108/ITSE-082020-0128

Field, A. (2000). Discovering Statistics using SPSS for Windows. London - Thousand Oaks New Delhi: Sage publications. 
Habidin, N. F., Zubir, A. F. M., Fuzi, N. M., Latip, N. A. M., \& Azman, M. N. A. (2015). Sustainable Manufacturing Practices in Malaysian Automotive Industry: Confirmatory Factor Analysis. Journal of Global Entrepreneurship Research, 5(1). https://doi.org/10.1186/S40497-015-0033-8

Haddad, M. E. O., Ferreira, N. S. C., \& Faria, A. A. (2014), "The Use of Educational Technologies in Distance Education: Enabling the Appropriation of Teaching and Learning Process", Open Journal of Social Sciences, Vol. 2 No. 1, pp. 54-58.

Hoofman, J., \& Secord, E. (2021). The Effect of COVID-19 on Education. Pediatric Clinics, 0(0). https://doi.org/10.1016/J.PCL.2021.05.009

Kaiser, H. F. (1974). An Index of Factorial Simplicity. Psychometrika 1974 39:1, 39(1), 31-36. https://doi.org/10.1007/BF02291575

Kamalluarifin, W. F. S. W., Aniza, F. N. F. M., Jayabalan, H., Saufi, M. L. H. M., \& Karib, S. H. F. (2018). Blended Learning: Satisfaction among Accounting Students in UNITEN KSHAS. Global Business and Management Research, Vol. 10 No. 3, pp. 547-557.

Kuhfeld, M., Soland, J., Tarasawa, B., Johnson, A., Ruzek, E., \& Liu, J. (2020). Projecting Potential Impact of COVID-19 School Closures on Academic Achievement: Https://Doi.Org/10.3102/0013189X20965918, 49(8), 549-565. https://doi.org/10.3102/0013189X20965918

Luca, K., de, McDonald, M., Montgomery, L., Sharp, S., Young, A., Vella, S., Holmes, M. M., Aspinall, S., Brousseau, D., Burrell, C., Byfield, D., Dane, D., Dewhurst, P., Downie, A., Engel, R., Gleberzon, B., Hollandsworth, D., Nielsen, A. M., O'Connor, L., ... French, S. D. (2021). COVID-19: How Has a Global Pandemic Changed Manual Therapy Technique Education in Chiropractic Programs Around the World? Chiropractic \& Manual Therapies 2021 29:1, 29(1), 1-11. https://doi.org/10.1186/S12998-021-00364-7

Maboe, K. A. (2017). Use Of Online Interactive Tools In An Open Distance Learning Context: Health Studies Students' Perspective. Health SA Gesondheid, 22, 221-227. https://doi.org/10.1016/J.HSAG.2017.02.001

Ministry of Health Malaysia: COVID-19 (Media Centre) - Press Release. (2020). http://www.moh.gov.my/index.php/pages/view/2019-ncov-wuhan-kenyataan-akhbar

Zakuan, M. Z. N. (2009). Structural Analysis of Total Quality Management, ISO/TS16949 and Organizational Performance in Malaysian and Thailand Automotive Industry.

Noor, W., Wan, H., \& Aziz, A. (2020). Pearson Correlation Coefficient of the Student Perception and Challenges towards Open and Distance Learning during COVID-19. Mathematical Sciences and Informatics Journal, 1(1), 96-103. http://www.mijuitmjournal.com

Nugroho, Y. S., Anifah, L., Sulistiyo, E., Cahyaningtias, S., \& Firmansyah, R. (2021). Analysis of Learning Quality With Internet-Based Distance Learning During the COVID-19 Pandemic. IJORER: International Journal of Recent Educational Research, 2(1), 96-110. https://doi.org/10.46245/IJORER.V2I1.81

Nunnally, J. C. (1978). Psychometric Theory, McGraw-Hill, New York, NY.

Okoye, K., Rodriguez-Tort, J. A., Escamilla, J., \& Hosseini, S. (2021). Technology-Mediated Teaching and Learning Process: A Conceptual Study of Educators' Response Amidst the COVID-19 Pandemic. Education and Information Technologies 2021, 1-33. https://doi.org/10.1007/S10639-021-10527-X

Pavlovic, A., DeFina, L. F., Natale, B. L., Thiele, S. E., Walker, T. J., Craig, D. W., Vint, G. R., Leonard, D., Haskell, W. L., \& Kohl, H. W. (2021). Keeping children healthy during and after COVID-19 pandemic: meeting youth physical activity needs. BMC Public Health, 
21(1). https://doi.org/10.1186/s12889-021-10545-x

Rafique, G. M., Mahmood, K., Warraich, N. F., \& Rehman, S. U. (2021). Readiness for Online Learning during COVID-19 pandemic: A survey of Pakistani LIS students. The Journal of Academic Librarianship, 47(3), 102346. https://doi.org/10.1016/J.ACALIB.2021.102346

Saidi, R. M., Sharip, A. A., Abd Rahim, N. Z., Zulkifli, Z. A., \& Zain, M. S. M. (2021). Evaluating Students' Preferences of Open and Distance Learning (ODL) Tools. Procedia Computer Science, 179, 955-961. https://doi.org/10.1016/J.PROCS.2021.01.085

Shah, S. S., Shah, A. A., Memon, F., Kemal, A. A., \& Soomro, A. (2021). Online Learning during the COVID-19 Pandemic: Applying The Self-Determination Theory In The 'New Normal.' Revista de Psicodidáctica (English Ed.), 26(2), 168-177.

https://doi.org/10.1016/J.PSICOE.2020.12.003

Shahrvini, B., Baxter, S. L., Coffey, C. S., MacDonald, B. V., \& Lander, L. (2021). Pre-clinical remote undergraduate medical education during the COVID-19 pandemic: a survey study. BMC Medical Education 2021 21:1, 21(1), 1-13. https://doi.org/10.1186/S12909020-02445-2

Stauffer, B. (2020). What's The Difference between Online Learning and Distance Learning? Applied Educational Systems.

Streiner, D. L. (1994). Figuring out factors: The use and misuse of factor analysis Can J Psychiatry 39 135-140 1: STN: 280:DyaK2czgs1aqtg\%3D\%3D 8033017

Veronika, V., Setiawan, W., \& Fazriyah, N. (2021). Students' Learning Motivation in Distance Learning During the COVID- 19 Pandemic Period at Primary School. International Conference on Elementary Education, 3(1), 359-363.

http://proceedings2.upi.edu/index.php/icee/article/view/1486

Yahya, N. A., Said, J. M., \& Yusof, A. M. (2021). Students' Self-Regulated Learning in Open and Distance Learning for Mathematics Course. EDUCATUM Journal of Science, Mathematics and Technology, 8(1), 1-5. https://doi.org/10.37134/EJSMT.VOL8.1.1.2021

Yusof, A. N. M., \& Ahmad, N. L. (2012). An Investigation on the Relationship between Online Distance Learning with Learning Usability. Procedia - Social and Behavioral Sciences, 65, 1066-1070. https://doi.org/10.1016/J.SBSPRO.2012.11.372

Zafar, T. S., \& Dayat, U. (2000). " Campus Free " Based On Self-Regulated Learning And Examples Based Campus To Increase Self-Study Ability And Learning Achievement. https://doi.org/10.31219/OSF.IO/P42ZX

Zulkipli, F., Jamian, N. H., Zulkifli, I. Z., \& Nopiah, Z. M. (2018). Investigation on Environmental Care Towards Sustainable Solid Waste Management Using Exploratory Factor Analysis At Uitm Tapah Campus. 1(1), 1-8. https://ir.uitm.edu.my/id/eprint/39938/ 